\title{
Gambaran Histopatologi Organ Hati dan Ginjal Mencit Balb/c setelah Pemberian Krim Ekstrak Teh Hijau (Camellia sinensis L.)
}

Nining Sugihartini, M. Alif Fajri

Fakultas Farmasi, Universitas Ahmad Dahlan Yogyakarta

Corresponding author: nining.sugihartini@pharm.uad.ac.id

\begin{abstract}
Background:Development of green tea extract formulation with the addition of enhancers to increase the ability of epigallocatechin gallate to penetrate the skin layers has been done. Objective: The purpose of this study was to determine the effect of green tea extract cream that containing enhancers on the profile of kidney and liver histopathology. Methods: The study used 4 groups which each group was treated with different concentrations of extract $(2,0 \% ; 2,5 \% ; 3,0 \% ; 3,5 \%)$ and 1 control group. After 24 hours and 14 days of application of the cream, the mice were sacrificed. The liver and kidneys were weighed and made preparations histopathology. Results: The results of the study showed that there similar $(p>0,05)$ of the weight ratio of the liver and kidneys of Balb/c mice after 24 hours and 14 days. As well the histopathological test indicated that there similar $(p>0,05)$ of the liver and kidneys after 24 hours and 14 days of administration of green tea extract cream. Conclusions: The levels concentration of green tea extract in cream $(2,0 \% ; 2,5 \% ; 3,0 \% ; 3,5 \%)$ that contain enhancers do not affect the liver and kidney histopathological of Balb/c mice.
\end{abstract}

Keywords Camellia sinensis L, histopathology, liver, kidney, enhancer

\begin{abstract}
Abstrak
Latar belakang: Pengembangan formulasi ekstrak teh hijau telah dilakukan dengan penambahan enhancer untuk meningkatkan kemampuan penetrasi epigalokatekin galat menembus lapisan kulit. Tujuan dari penelitian ini adalah mengetahui pengaruh pemberian krim ekstrak teh hijau yang mengandung enhancer terhadap gambaran histopatologi ginjal dan hati mencit. Metode: Penelitian ini menggunakan 4 kelompok mencit galur Balb/C yang masing-masing diberikan konsentrasi ekstrak yang berbeda $(2,0 \% ; 2,5 \% ; 3,0 \%$; 3,5\%) dan 1 kelompok kontrol. Setelah 24 jam dan 14 hari pemberian krim, mencit dikorbankan. Organ hati dan ginjal diambil untuk dibuat preparat histopatologi. Hasil: Hasil uji menunjukkan bahwa tidak ada perbedaan berat hati dan ginjal mencit setelah pemberian krim selama 24 jam dan 14 hari. Demikian juga dengan gambaran hasil uji histopatologi hati dan ginjal mencit setelah pemberian krim selama 24 jam dan 14 hari. Kesimpulan: Konsentrasi ekstrak teh hijau dalam krim (2,0\%; 2,5\%; 3,0\%; 3,5\%) yang mengandung enhancer tidak mempengaruhi gambaran histopatologi hati dan ginjal mencit galur $\mathrm{Balb} / \mathrm{c}$.
\end{abstract}

Kata Kunci: Camellia sinensis L, histopatologi, hati, ginjal, enhancer 


\section{Pendahuluan}

Teh hijau mengandungepigallocatechin gallate (EGCG) sebesar 51,88\%. Epigalokatekin galat sebagai kandungan utama dalam ekstrak teh hijau tersebut berkhasiat sebgai antiinflamasi (Butt dan Sultan, 2009; Nagle dkk., 2006; Cavet dkk, 2011; Dona dkk, 2003). Penghantaran EGCG dalam ekstrak teh hijau dalam bentuk sediaan topikal krim merupakan saah satu pilihan untuk penghantaran sebagai antiinflamasi (Sailendra dkk., 2006 dan Fang dkk., 2007). Dalam memformulasikan krim ekstrak teh hijau diperlukan zat tambahan yang dapat meningkatkan penetrasi ke daerah inflamasi yang biasa disebut sebgai enhancer. Pada penelitian tahap sebelumnya telah diteliti komposisi enhancer yang optimal berupa campuran asam oleat, propilen glikol dan minyak atsiri dalam meningkatkan penetrasi EGCG menembus lapisan kulit (Sugihartini dkk., 2011).

Mekanisme asam oleat dalam meningkatkan penetrasi absorpsi perkutan berdasarkan kemampuannya mengubah fluiditas lipida dalam stratum korneum yang dapat meningkatkan permeabilitas lapisan stratum korneum (Darijanto dkk., 2004 ; Jiang dan Wang, 2005). Selain itu propilenglikol dilaporkan dapat melarutkan keratin pada stratum korneum (Trommer dan Neubert, 2006) dan minyak atsiri temulawak dengan kandungan terpen kamfora (Sudarsono, 2004) yang berdasarkan penelitian dapat berfungsi sebagai enhancer (Das dkk, 2006) dengan membentuk jembatan hidrogen dengan ceramid sehingga dapat memecah ikatan lipid stratum korneum (Lahora dkk, 2011).Oleh karena itu adanya enhancer dalam formula krim ekstrak teh hijau memungkinkan senyawa masuk ke dalam pembuluh darah dan dapat terakumulasi pada organ penting dalam tubuh seperti organ hati dan ginjal yang berakibat pada keracunan obat. Seperti sudah diketahui bahwaobat yang masuk ke dalam tubuh akan dimetabolisme di hati dan setelah didistribusikan ke seluruh tubuh akan dikeluarkan melewati ginjal. Hal ini juga mengacu pada hasil penelitian Kapetanovic dkk. (2009) yang menunjukkan bahwa pemberian ekstrak teh hijau selama 9 bulan pada hewan uji anjing dengan dosis 0,200,500,1000 $\mathrm{mg} / \mathrm{kg} / \mathrm{hari}$ menunjukkan adanya hubungan antara kematian dan gejala kesakitan pada hewan uji dengan tingkat dosis. Oleh karena itu diperlukan penelitian lanjutan untuk mengetahui keamanan krim apabila nanti dipergunakan konsumen.

\section{BAHAN DAN METODE}

Bahan
Bahan yang digunakan antara lain simplisia teh hijau yang diperoleh dari Samigaluh Kulonprogo, bahan pembuat krim dengan derajat farmasetis (asam stearat, setil alkohol, stearil alkohol, trietanolamin, gliserin, asam sitrat, metil paraben, asam oleat, propilen glikol, minyak atsiri temulawak, tween 80 , span 80 , vitamin C) larutan $\mathrm{NaCl}$ fisiologis, larutan formalin $10 \%$.

Alat yang digunakan antara lain timbangan, panci infusa, waterbath (memmerth), corong pisah, rotari evaporator (Buchi) dan peralatan bedah.

\section{Metode Penelitian \\ Pembuatan Ekstrak Teh Hijau}

Ekstrak teh hijau diperoleh dengan metode infundasi. Selanjutnya infusa yang telah diuapkan difraksinasi dengan etil asetat sebanyak 3 kali dan dikentalkan dengan menggunakan rotari evaporator. Setelah kental kemudian diuapkan di atas waterbath sampai etil asetatnya habis sehingga diperoleh serbuk kering ekstrak teh hijau (Sugihartini, 2013).

\section{Pembuatan Sediaan Krim Ekstrak Teh Hijau}

Metode yang digunakan dalam pembuatan krim ekstrak teh hijau yaitu metode peleburan dengan komposisi disajikan pada tabel I. Cara pembuatannya yaitu sebagai berikut bahan yang bersifat larut dalam minyak yaitu asam stearat, setil alkohol, stearil alkohol, asam sitrat, asam oleat dan Span 80 dilelehkan pada waterbath dengan suhu $75 \mathrm{C}$. Sedangkan untuk bahan yang larut dalam air yaitu trietanolamin, gliserin, metil paraben, propilen glikol, Tween 80 dan Vitamin $\mathrm{C}$ juga dileburkan pada suhu yang sama. Setelah itu pencampuran bahanbahan yang telah dileburkan dilakukan pada mortir yang telah dihangatkan lalu kedua campuran diaduk sampai homogen dan terakhir tambahkan minyak atsiri temulawak dan ekstrak teh hijau (Sugihartini, 2013).

Tabel 1. Formulasi Krim dengan Variasi Konsentrasi Ekstrak Teh Hijau

\begin{tabular}{|l|c|c|c|c|}
\hline \multirow{2}{*}{ Nama bahan } & \multicolumn{4}{|c|}{$\begin{array}{c}\text { Formulasi dalam berbagai } \\
\text { tingkat kadar }\end{array}$} \\
\cline { 2 - 5 } & F I & F II & F III & F IV \\
\hline Ekstrak teh hijau & 0,06 & 0,075 & 0,09 & 0,105 \\
\hline Asam stearat & 5,14 & 5,14 & 5,14 & 5,14 \\
\hline Setil alkohol & 2,75 & 2,75 & 2,75 & 2,75 \\
\hline Stearil alkohol & 5,14 & 5,14 & 5,14 & 5,14 \\
\hline Trietanolamin & 1,28 & 1,28 & 1,28 & 1,28 \\
\hline Gliserin & 7,72 & 7,72 & 7,72 & 7,72 \\
\hline
\end{tabular}




\begin{tabular}{|l|c|c|c|c|}
\hline Asam sitrat & 0,64 & 0,64 & 0,64 & 0,64 \\
\hline Metil paraben & 0,25 & 0,25 & 0,25 & 0,25 \\
\hline Asam oleat & 6,04 & 6,04 & 6,04 & 6,04 \\
\hline Propilen glikol & 7,17 & 7,17 & 7,17 & 7,17 \\
\hline $\begin{array}{l}\text { Minyak atsiri } \\
\text { temulawak }\end{array}$ & 6,79 & 6,79 & 6,79 & 6,79 \\
\hline Tween 80 & 10 & 10 & 10 & 10 \\
\hline Span 80 & 1 & 1 & 1 & 1 \\
\hline Vitamin C & 1 & 1 & 1 & 1 \\
\hline Air & $\begin{array}{c}\text { ad } \\
100\end{array}$ & ad 100 & ad 100 & $\begin{array}{c}\text { ad } \\
100\end{array}$ \\
\hline
\end{tabular}

\section{Uji Efek Pemberian Krim Ekstrak Teh Hijau}

Evaluasi formula krim dilakukan dengan menggunakan mencit Balb/c. Sebelum mendapat perlakuan, 50 ekor mencit mengalami masa adaptasi dengan dikandangkan individual dan diberi pakan standar selama seminggu secara ad libitum. Mencit tersebut lalu dibagi menjadi 5 kelompok yang ditentukan secara acak. Setiap kelompok terdapat 10 ekor mencit dimana lima mencit untuk pengamatan 24 jam dan 5 ekor mencit untuk pengamatan 14 hari guna melihat efek toksik yang timbulnya tertunda. Kelima kelompok tersebut meliputi kelompok kontrol (K) (tidak diolesi krim), kelompok perlakuan 1 (P1) (diolesi krim kadar 2,0\%), kelompok perlakuan 2 (P2) (diolesi krim kadar 2,5\%), kelompok perlakuan 3 (P3) (diolesi krim kadar 3,0\%), kelompok perlakuan 4 (P4) (diolesi krim kadar 3,5\%). Pada kelompok mencit perlakuan sehari sebelumnya dicukur pada punggung. Pada saat perlakuan krim dioleskan sebanyak $100 \mathrm{mg}$ per mencit dengan luas $1 \mathrm{~cm}^{2}$ dari total luas permukaan. Pengamatan dilakukan setelah 24 jam dan 14 hari.

\section{Pemeriksaaan Hewan Uji}

Kelompok mencit yang mendapatkan perlakuan krim, setelah 24 jam dan 14 hari dibunuh (dekapitasi) dengan metode cervical dislocation. Setelah itu dilakukan pembedahan untuk pengambilan hati dan ginjal. Organ hati dan ginjal tersebut dicuci dengan $\mathrm{NaCl}$ 0,9\% danditimbang sebagai dasar perhitungan rasio berat organ yang dihitung dengan rumus: (berat organ (gram)/berat badan hewan uji saat dikorbankan (gram)x100\%. Setelah itu organ hati dan ginjal dimasukkan dalam wadah yang berisi larutan pengawet larutan formalin 10\% untuk dibuat preparat histopatologinya.

\section{Pembacaan Preparat Histopatologik}

Preparat hati dan ginjal dibaca dalam 5 lapangan pandang yaitu pada keempat sudut dan bagian tengah preparat dengan perbesaran 100x dan 400x dengan batasan jumlah sel 20 sel tiap lapang pandang. Sasaran yang dibaca untuk organ hati adalah perubahan struktur sel normal atau inti sel karena inti sel merupakan bagian terpenting dari organ hati. Sedangkan sasaran yang dibaca untuk organ ginjal adalah perubahan struktur histologis tubulus kontortus proksimal ginjal mencit karena sel epitel tubulus proksimal peka terhadap anoksia dan mudah hancur karena keracunan akibat kontak dengan bahanbahan yang diekskresikan melalui ginjal.

\section{Hasil Dan Pembahasan}

\section{Perhitungan Rasio Berat Organ}

Pengamatan terhadap organ hati dan ginjal dilakukan setelah 24 jam dan 14 hari pemberian krim ekstrak teh hijau. Tujuan pengamatan setelah 24 jam adalah untuk melihat efek segera dan pengamatan setelah 14 hari adalah melihat efek tertunda. Hasil rasio berat organ hewan uji 24 jam setelah pemberian sediaan uji dapat dilihat pada Tabel 2 dan setelah 14 hari pada Tabel 3.

Tabel 2. Rasio berat organ mencit setelah 24 jam pemberian krim ekstrak teh hijau

\begin{tabular}{ccccccc}
\hline No & Organ & $\begin{array}{c}\text { Kontrol } \\
\text { positif }\end{array}$ & $\begin{array}{c}\text { Kadar } \\
2,0 \%\end{array}$ & $\begin{array}{c}\text { Kadar } \\
2,5 \%\end{array}$ & $\begin{array}{c}\text { Kadar } \\
3,0 \%\end{array}$ & $\begin{array}{c}\text { Kadar } \\
3,5 \%\end{array}$ \\
\hline 1 & $\begin{array}{c}\text { Hati } \\
(\%)\end{array}$ & $4,09 \pm 0,37$ & $4,23 \pm 0,42$ & $4,26 \pm 0,55$ & $4,43 \pm 0,64$ & $4,26 \pm 1,08$ \\
2 & $\begin{array}{c}\text { Ginjal } \\
(\%)\end{array}$ & $1,34 \pm 0,06$ & $1,34 \pm 0,15$ & $1,37 \pm 0,08$ & $1,38 \pm 0,16$ & $1,39 \pm 0,09$
\end{tabular}

Tabel 3. Rasio berat organ mencit setelah 14 hari pemberian krim ekstrak teh hijau (Camellia sinensis L)

\begin{tabular}{ccccccc}
\hline No & Organ & $\begin{array}{c}\text { Kontrol } \\
\text { positif }\end{array}$ & $\begin{array}{c}\text { Kadar } \\
2,0 \%\end{array}$ & $\begin{array}{c}\text { Kadar } \\
2,5 \%\end{array}$ & Kadar 3,0\% & $\begin{array}{c}\text { Kadar } \\
3,5 \%\end{array}$ \\
\hline 1 & $\begin{array}{l}\text { Hati } \\
(\%)\end{array}$ & $4,83 \pm 1,37$ & $4,62 \pm 0,39$ & $4,96 \pm 0,44$ & $4,43 \pm 0,64$ & $4,79 \pm 0,12$ \\
2 & $\begin{array}{l}\text { Ginjal } \\
(\%)\end{array}$ & $1,46 \pm 0,09$ & $1,41 \pm 0,10$ & $1,49 \pm 0,28$ & $1,42 \pm 0,45$ & $1,40 \pm 0,08$ \\
\hline
\end{tabular}

Hasil uji statistik pada kedua data menunjukkan bahwa tidak ada perubahan rasio berat organ mencit setelah pemberian sediaan krim ekstrak teh hijau pada berbagai kelompok perlakuan.Ini dapat diartikan dengan adanya komposisi enhancer pada sediaan krim ekstrak teh hijau setelah 24 jam dan 14 hari pemberian krim tersebut tidak mempengaruhi berat organ hati dan ginjal. Enhancer 
membantu penetrasi EGCG dalam penghantarannya ke daerah inflamasi sampai pada lapisan viable dermis sehingga ekstrak yang masuk kedalam pembuluh darah tidak terlalu banyak. Oleh karena itu tidak mempengaruhi berat organ hati dan ginjal mencit Balb/c.

\section{Gambaran Histopatologik}

Hasil pemeriksaan histopatologi pada organ hati dan ginjal setelah 24 jam disajikan pada Tabel 4. Hasil pemeriksaan histopastologi pada organ hati dan ginjal setelah dilakukan 24 jam pemberian krim ekstrak teh hijau menunjukkan bahwa pada semua kelompok tidak mengalami perubahan. Ini dapat diartikan dengan adanya komposisi enhancer pada sediaan krim ekstrak teh hijau setelah 24 jam pemberian krim tersebut tidak mempengaruhi gambaran histopatologi organ hati dan ginjal. Kemungkinan hal tersebut disebabkanenhancermeningkatkan penetrasi senyawa EGCG hanya mencapai viable dermis, sehingga ekstrak yang masuk kedalam pembuluh darah tidak terlalu banyak dan tidak mempengaruhi gambaran histopatologi organ hati dan ginjal mencit Balb/c.

Hasil pemeriksaan histopatologi organ hati setelah pemberian krim selama 14 hari disajikan pada tabel 5 . Dari Tabel5 dapat dilihat bahwa setelah dilakukan 14 hari pemberian krim ekstrak teh hijau organ hati yang mengalami nekrosis terjadi pada kelompok II sebanyak 1 ekor mencit dan pada kelompok IV terdapat 2 ekor mencit. Infiltrasi sel terjadi pada kelompok III sebanyak 2 ekor mencitserta pada kelompok V sebanyak 2 ekor mencit. Hal ini juga terjadi pada kelompok I (kontrol) dimana terdapat 1 ekor mencit mengalami nekrosis dan 1 ekor mencit mengalami infiltrasi sel. Gambaran histopatologi organ hati yang normal dan mengalami nekrosis disajikan pada gambar 1 dan 2 .
Tabel 4. Hasil pemeriksaan histopatologik organ hati dan ginjal mencit setelah 24 jamsebelumnya diberikan krim ekstrak teh hijau (Camellia sinensis L).

\begin{tabular}{|c|c|c|c|}
\hline \multirow[t]{2}{*}{ Kelompok } & \multirow[t]{2}{*}{ No } & \multicolumn{2}{|c|}{$\begin{array}{c}\text { Hasil Pemeriksaan } \\
\text { Histopatologi }\end{array}$} \\
\hline & & Hati & Ginjal \\
\hline Kelompok & 1 & - & - \\
\hline I & 2 & - & - \\
\hline \multirow[t]{3}{*}{ Kontrol } & 3 & - & - \\
\hline & 4 & - & - \\
\hline & 5 & - & - \\
\hline Kelompok & 1 & - & - \\
\hline II & 2 & - & - \\
\hline \multirow[t]{3}{*}{ Krim kadar 2,0\% } & 3 & - & - \\
\hline & 4 & - & - \\
\hline & 5 & - & - \\
\hline Kelompok & 1 & - & - \\
\hline III & 2 & - & - \\
\hline \multirow[t]{3}{*}{ Krim kadar 2,5\% } & 3 & - & - \\
\hline & 4 & - & - \\
\hline & 5 & - & - \\
\hline Kelompok & 1 & - & - \\
\hline IV & 2 & - & - \\
\hline \multirow[t]{3}{*}{ Krim kadar 3,0\% } & 3 & - & - \\
\hline & 4 & - & - \\
\hline & 5 & - & - \\
\hline Kelompok & 1 & - & - \\
\hline $\mathrm{V}$ & 2 & - & - \\
\hline \multirow[t]{3}{*}{ Krim kadar 3,5\% } & 3 & - & - \\
\hline & 4 & - & - \\
\hline & 5 & - & - \\
\hline
\end{tabular}

Keterangan: (-) menunjukkan tidak adanya perubahan histopatologi pada organ

Tabel 5. Hasil pemeriksaan histopatologi organ mencit 14 hari setelah pemberian krim ekstrak teh hijau (Camellia sinensis L)

\begin{tabular}{|c|c|c|c|}
\hline \multirow{2}{*}{ Kelompok } & \multirow{2}{*}{ No } & \multicolumn{2}{|c|}{ Hasil Pemeriksaan Histopatologi } \\
\hline & & Hati & Ginjal \\
\hline Kelompok & 1 & - & - \\
\hline I & 2 & $\mathrm{~N}$ & - \\
\hline \multirow[t]{3}{*}{ Kontrol } & 3 & - & - \\
\hline & 4 & $\mathrm{R}$ & - \\
\hline & 5 & - & - \\
\hline Kelompok & 1 & - & - \\
\hline II & 2 & $\mathrm{~N}$ & - \\
\hline \multirow[t]{3}{*}{ Krim kadar 2,0\% } & 3 & - & - \\
\hline & 4 & - & - \\
\hline & 5 & - & - \\
\hline Kelompok & 1 & $\mathrm{R}$ & - \\
\hline III & 2 & $\mathrm{R}$ & - \\
\hline \multirow[t]{3}{*}{ Krim kadar $2,5 \%$} & 3 & - & - \\
\hline & 4 & - & - \\
\hline & 5 & - & - \\
\hline Kelompok & 1 & - & - \\
\hline IV & 2 & $\mathrm{~N}$ & - \\
\hline \multirow[t]{3}{*}{ Krim kadar 3,0\% } & 3 & - & - \\
\hline & 4 & - & - \\
\hline & 5 & $\mathrm{~N}$ & - \\
\hline Kelompok & 1 & - & - \\
\hline V & 2 & $\mathrm{R}$ & - \\
\hline \multirow[t]{3}{*}{ Krim kadar 3,5\% } & 3 & $\mathrm{R}$ & - \\
\hline & 4 & - & - \\
\hline & 5 & - & - \\
\hline
\end{tabular}


Keterangan:

$\mathrm{N}$ : Nekrosis

R: Infiltrasi sel radang

(-) menunjukkan tidak adanya perubahan histopatologi pada organ

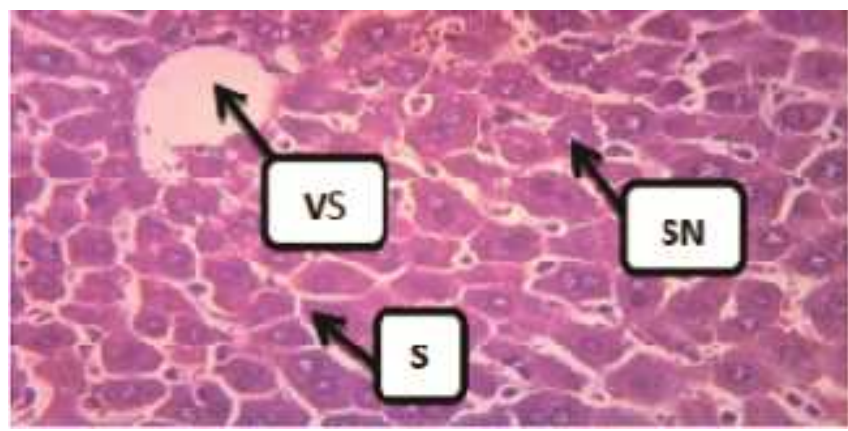

Gambar 1. Gambaran histopatologik organ hati normal setelah 14 hari pemberian krim ekstrak teh hijau (Camellia sinensis L) pada kelompok kontrol dengan pengecatan hematoxylin-eosin.

Keterangan: VS = Vena sentralis, $\mathrm{SN}=$ Inti sel normal, $\mathrm{S}=$ Sinusoid

Nekrosis merupakan kematian jaringan, ditandai dengan adanya inti yang telah mati merupakan tingkat degenerasi (Robbins et al., 2007). Terjadinya nekrosis yang disebabkan oleh zat toksik dari spesies bakteri ini secara mikroskopik tampak inti-inti piknotik. Sesudah beberapa hari sisa-sisa inti menghilang, sitoplasma tampak bebutir, warna merah tua seperti terlihat pada Gambar 2 . Sampai beberapa minggu rangka sel masih dapat dilihat (Pringgoutomo, 2002). Terdapat pula sel yang mengalami infiltrasi seperti disajikan pada gambar 3. Infiltrasi yaitu penyusupan sel atau masuknya sel-sel radang dari luar jaringan (Darmawan dan Himawan, 1994). Secara mikroskopik, jaringan infiltrasi sel seluruhnya ditandai dengan adanya sel radang berwarna keunguan. Adanya perubahan histopatologi organ hati setelah pemberian EGCG juga ditunjukkan oleh penelitian Kapetanovic dkk. (2009) yang menunjukkan bahwa pada pemberian kapsul yang mengandung katekin pada hewan uji anjing yang dipuasakan menunjukkan adanya perubahan pada organ hati yaitu mengalami hematopoiesis dan pigmented macrophages setelah pemberian dosis $176 \mathrm{mg} / \mathrm{kg} / \mathrm{hari}$ dan $200 \mathrm{mg} / \mathrm{kg} / \mathrm{hari}$. Pada penelitian tersebut bentuk sediaannya adalah kapsul sehingga zat aktif langsung diserap dan mengalami metabolisme di hati. Sedangkan pada penelitian ini bentuk sediaannya adalah krim di mana
EGCG masuk ke lapisan kulit dengan bantuan enhancer dan apabila mencapai pembuluh darah pada jaringan dermis dapat mengalami absoprsi dan kemudian diedarkan ke seluruh tubuh. Hal ini menunjukkan bahwa adanya absorpsi EGCG kemungkinan menyebabkan efek buruk pada organ hati. Penelitian lebih lanjut perlu dilakukan untuk memperkuat hasil penelitian ini.

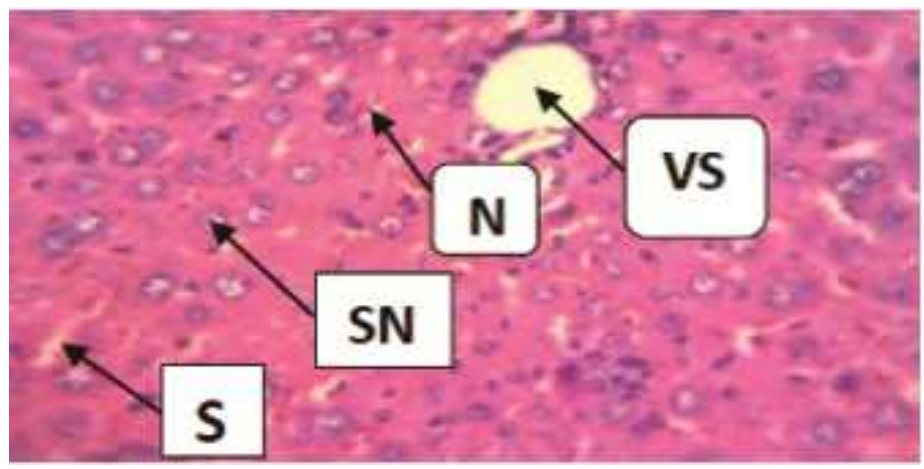

Gambar 2. Gambaran histopatologik organ hati yang mengalami nekrosis $(\mathrm{N})$ setelah 14 hari pemberian krim ekstrak teh hijau (Camellia sinensis L) pada kelompok kontrol dengan pengecatan hematoxylin-eosin.

Keterangan: $\mathrm{N}=$ Nekrosis, $\mathrm{VS}=$ Vena sentralis, $\mathrm{SN}=\mathrm{Inti}$ sel normal, $\mathrm{S}=$ Sinusoid.

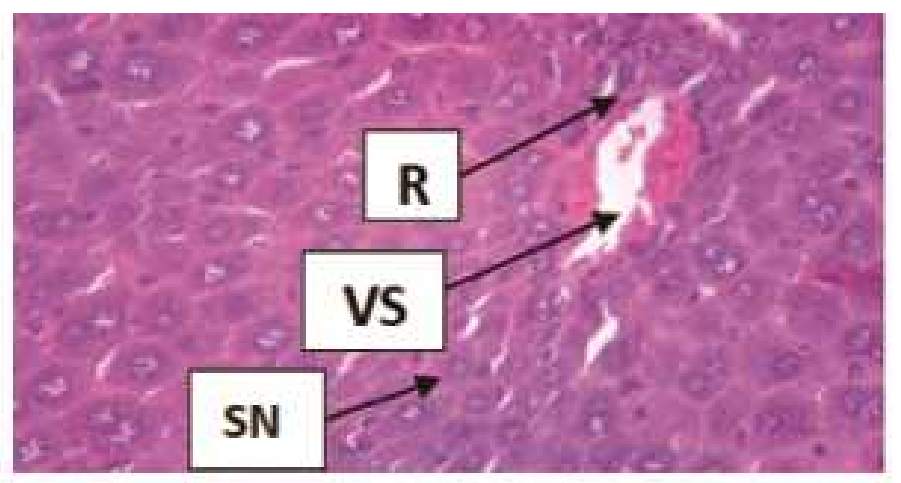

Gambar 3. Gambaran histopatologik organ hati yang mengalami infiltrasi sel radang (R) setelah 14 hari pemberian krim ekstrak teh hijau (Camellia sinensis L) pada kelompok kontrol dengan pengecatan hematoxylineosin.

Keterangan: $\mathrm{R}=$ infiltrasi sel radang.

Di sisi lain pada organ ginjal di semua kelompok tidak terdapat perubahan atau kerusakan sel atau organ.Organ ginjal dikatakan normal apabila terdapat 
glomelurus, kapsula bowman dan inti sel yang normal serta tidak mengalami nekrosis dan infiltasi sel seperti terlihat pada Gambar 4. Sehingga dapat diartikan bahwa adanya komposisi enhancer pada sediaan krim ekstrak teh hijau setelah 14 hari pemberian krim tersebut tidak mempengaruhi gambaran histopatologik organ ginjal. Hal ini menunjukkan bahwa enhancer dalam formulasi krim meningkatkan penetrasi senyawa aktif tetapi tidak mempengaruhi gambaran histopatologik organ ginjal mencit Balb/c setelah pemberian 24 jam maupun 14 hari. Penelitian lainnya juga menunjukkan bahwa pemberian EGCG ternyata tidak memberikan efek buruk pada organ. Penelitian Isbrucker dkk (2006) menunjukkan bahwa pemberian EGCG dosis $500 \mathrm{mg} / \mathrm{kg} /$ hari pada hewan uji tikus yang diberikan selama 13 minggu tidak memberikan efek samping pada hewan uji. Hal ini sesuai juga dengan penelitian Takami dkk. (2008) yang menunjukkan bahwa pemberian katekin konsentrasi $1,25 \%$ yang setara dengan $764 \mathrm{mg} / \mathrm{kgBB} / \mathrm{hari}$ untuk laki-laki dan $820 \mathrm{mg} / \mathrm{kgBB} / \mathrm{hari}$ untuk wanita tidak memberikan efek buruk pada tubuh berdasarkan hasil uji hematologi dan histopatologi.

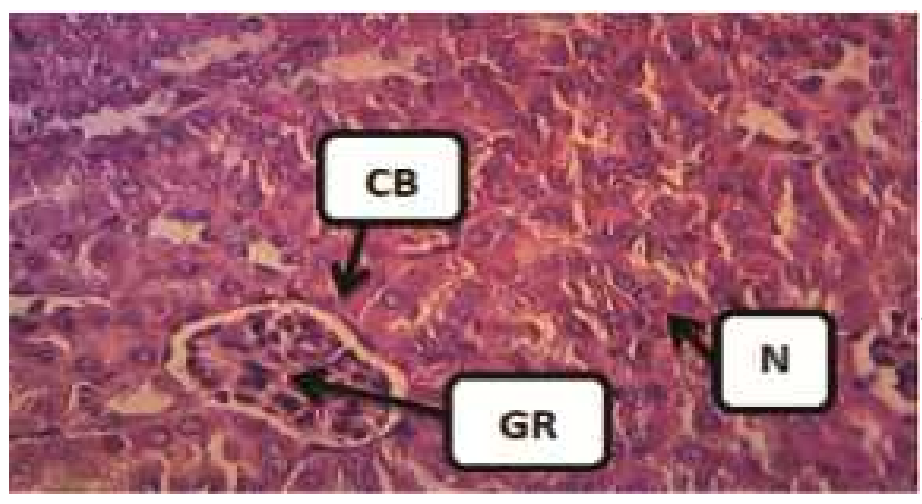

Gambar 4. Gambaran histopatologik organ ginjal normal dengan pengecatan hematoxylin-eosin.

Keterangan: GR = Glomerulus, $\mathrm{CB}=$ Capsula bowman, $\mathrm{N}$ $=$ Inti sel normal.

\section{KESIMPULAN}

Formula krim ekstrak teh hijau kadar 2,0\%; 2,5\%; 3,0\%; 3,5\% tidak mempengaruhi gambaran histopatologik ginjal mencit $B a l b / c$ setelah pemberian selama 24 jam dan 14 hari akan tetapi memberikan efek pada organ hati setelah pemberian selama 14 hari.

\section{UCAPAN TERIMA KASIH}

Penulis mengucapkan terimaksih kepada DIKTI yang telah memberikan dana penelitian ini dengan mekanisme
Hibah Bersaing tahun 2013.

\section{Daftar Pustaka}

Butt MS and Sultan MT. 2009.Green Tea : Nature's defense against malignancies, critical reviews in food science and nutrition.49;463-473.

Cavet ME, Harrington KL. Vollmer TR. Ward KW. Zhang JZ. 2011 Anti-inflammatory and antioxidative effects of the green tea polyphenol epigallocatechin gallate in human corneal epithelial cells.Molecular Vision. 17; 533.

Darijanto ST. Maria I. Heni S. 2004. Uji pengaruh asam oleat terhadap stabilitas dan difusi prednisolon dari sediaan gel secara in vitro serta uji efek antiradang secara in vivo.Acta Pharmaceutica Indonesia. XXIX; $2 ; 59-71$.

Darmawan S. dan Himawan S. 1994.Patologi. Fakultas Kedokteran Bagian Patologi Anatomi Universitas Indonesia. Jakarta

Das M. Bhattacharya A.and Ghosal SJ. 2006. Effect of different terpene containing essential oils on percutaneous absorption of trazodone hydrochloride trough mouse epidermis.Drug Delivery.13;425-431.

Fang JY. Tsai TH. Lin YY. Wong WW. Wang MN. Huang JF. 2007. Transdermal delivery of tea cathecins and theophylline enhanced by terpenes:a mechanistic study. Biological \& Pharmaceutical Bulletin. 30;2;343-349.

Isbrucker RA. Edwards JA. Wolz E. Davidovich A. and Bausch. J. 2006 Safety studies on epigallocatechin gallate (EGCG) preparations. Part 2: dermal, acute and short-term toxicities studies.Food and Chemical Toxicology. 44;636-650

Jiang J.and Wang R. 2005. How different molarities of oleic acid as enhancer exert its effect on optical clearing on skin tissue in vitro.Journal of X-Ray Science and Technology.13;3;149-159.

Kapetanovic IM. Crowell J.A. Krishnaraj R. Zakharov A. Lindeblad M. and Lyubinov A. 2009. Exposure and toxicity of green tea polyphenols in fasted and nonfasted dogs.Toxicology. 260;28-36

Lahora D. Chaudary V. Shah SK. Swami G. Chaudary G. and Saraf SA. 2011. Terpenes: Natural skin penetration enhancers in transdermal drug delivery system.International Journal of Pharma Research and Development. 2;12; 39-45.

NagleDG. Ferreira D. and Zhoua YD. 2006. Epigallocatechin-3-gallate (EGCG): Chemical and biomedical perspectives. Phytochemistry. 67;17;1849-1855.

Pringgoutomo SS. Himawan A. Tjarta. 2002. Buku ajar patologi I. Sagung Seto. Jakarta.

Robbins SL. Cotran RS. dan Kumar V. 2007. Buku ajar Patolog.Ed.7 Vol.1.Buku Kedokteran EGC. Jakarta

Sailendra N. Nichenametla. Taruscio TG. Barney DL. Exon JH. 2006. A review of the Effects and 
mechanisms of polyphenolics in cancer. Crittical Review in Food Science and Nutrition. 46;161-183.

Sudarsono. 2004. Kamfora, Salah satu komponen minyak atsiri rimpang temulawak (Curcuma xanthorrhiza Roxb.) dari kebun tanaman obat PT. Nyonya Meneer, Karangjati.Majalah Farmasi Indonesia. $15 ; 4 ; 194-200$

Sugihartini N. Fudholi A. Pramono S dan Sismindari. 2011. Optimation composition of oleic acid, propilenglycol and volatile oil of Curcuma xanthorriza as enhancer of transport of epigalocatathecin gallat in green tea extract with simplex lattice design methode. Jurnal Bahan Alam Indonesia. 7;7;393-395.

Sugihartini N. 2013. Optimasi komposisi enhancer dan emulgator pada formulasi krim fraksi etil asetat ekstrak teh hijau (Camelia sinensis, L) sebagai sediaan topikal antiinflamasi. Disertasi. Program Pascasarjana Farmasi. Universitas Gadjah Mada.

Takami S. Imai T. Hasumura M. Cho YM. Onose J. And Hirose M. 2008. Evaluation of toxicity of green tea catechins with 90-day dietary administration to F344 rats.Food and Chemical Toxicology. 46;22242229

Trommer H.and Neubert R. 2006. Overcoming the stratum corneum: the modulation of skin penetration a review.Skin Pharmacology and Physiology.19;2;106-121. 